\title{
AMPHIBIAN DECLINES IN THE GREATER YELLOWSTONE ECOSYSTEM: TOADS WITH Protection From BaCterial DiSEASE
}

\author{
JEREMY E. HAWK $\downarrow$ CHARLES R. PETERSON \\ DEPARTMENT OF BIOLOGICAL SCIENCES $\downarrow$ IDAHO STATE UNIVERSITY \\ POCATELLO
}

\section{$\downarrow \quad$ INTRODUCTION}

During the past forty years, biologists have become increasingly concerned about the decline and disappearance of various amphibian species throughout the world (Wyman 1990, Wake 1991). An example of an amphibian decline in western North America is that of the Boreal Toad (Bufo boreas). A previously widespread and abundant species, the Boreal Toad has undergone large population declines and is now a candidate for threatened and endangered status in the eastern half of its range (Stebbins and Cohen 1995, Federal Register 1995).

Decreases in Boreal Toad abundance and distribution have been observed in Colorado, eastern Wyoming, and eastern Utah (Corn et al. 1989). From 1971-82, eleven Boreal Toad populations disappeared from the West Elk Mountains of Colorado (Carey 1993). During this eleven-year period, numerous individuals were observed exhibiting symptoms of redleg, a welldocumented disease in amphibians caused by the bacterium Aeromonas hydrophila (Russel 1898, Emerson and Norris 1905, Kulp and Borden 1942, Reed and Toner 1942, Dusi 1949, Hunsaker and Potter 1960, Hird et. al. 1981, Nyman 1986, Carey 1993). This disease was considered responsible for the decline and ultimate extinction of these eleven toad populations. These extinctions led Carey to propose a hypothesis regarding the disease process which is stated as follows: (1) Some environmental factor or synergistic effects of more than one factor changes sufficiently to cause sublethal "stress;" (2) This stress directly causes suppression of the immune system, or indirectly causes immunosuppression by effecting elevated secretion of adrenal cortical hormones; (3) Immunosuppression, coupled with the apparent effect of cold body temperatures on the ability of immune systems of ectothermic animals to fight disease, leads to infection by Aeromonas or other infectious agents, and to subsequent death of individuals and extinction of populations.

Another area where Boreal Toads have apparently declined is within the Greater Yellowstone Ecosystem (GYE). Field surveys during 1991 revealed Boreal Toads to be less widespread and less abundant than in the past, especially in the southern portion of the GYE (Peterson et al. 1992, Koch and Peterson 1995). This contradicts Carpenter's earlier description of Boreal Toads as being the most wide-spread amphibian in the Jackson Hole region (1953). During the 1991 field season, a interesting relationship was detected among toad breeding sites. At sites where toads were still breeding, there was an unusual water chemistry that included such 
components as high conductivity and high acid neutralizing capacity (Peterson et. al. 1992); many of these breeding sites were also geothermally influenced.

Various factors have been implicated in amphibian declines worldwide including ultraviolet radiation, drought, pollution, introduced species, acid precipitation, and habitat modification (Blaustein \& Wake 1990; Phillips 1990; Wyman 1990; Pechmann et. al. 1991). Drought in the late 1980 's and early 1990's was responsible for reduced breeding success of Boreal Toads at some locations within the GYE (Bartelt, unpublished data). However, drought does not appear to explain why Boreal Toads have declined in other portions of the GYE. Other unlikely causes for Boreal Toad declines within the GYE are acid precipitation, due to intermediate $\mathrm{pH}$ and/or adequate buffering capacity of most amphibian sites in the Rocky Mountains (Corn 1992); introduced species like trout, because predatory fish have been shown to avoid consuming Bufo tadpoles under laboratory conditions, (Voris and Bacon, Brodie et.al. 1987); and habitat modification within the GYE does not appear extensive enough to explain the declines. Because redleg has been implicated in Boreal Toad declines elsewhere (Carey 1993), we suspect it may have contributed to declines within the GYE.

Interestingly, a negative correlation between densities of $A$. hydrophila, a causative agent of redleg, and conductivity in freshwater environments has been described (Hazen et al. 1978). If this relationship were to be demonstrated within the GYE, it could help explain why toad populations appear to be persisting within these high conductivity/geothermally influenced sites.

Based on the observations that Boreal Toads appear to be primarily breeding in areas of high conductivity and that densities of $A$. hydrophila may decrease with conductivity, we expected to observe low densities of $A$. hydrophila within these high conductivity/geothermally influenced sites. Our hypothesis was that the low bacterial densities may reduce the risk of infection and outbreak of the disease. Our overall objective is to determine if Boreal Toads are protected from infection(s) with $A$. hydrophila by breeding in areas of high conductivity/geothermal influence. However, before we can address our overall objective, we needed to determine the relationships among toad breeding, water chemistry, and densities of $A$. hydrophila in the field. We conducted field studies during the summer of 1997 to address the following questions. After addressing these questions, we will conduct laboratory studies in 1998 to determine if Boreal Toads are protected from infection(s) with $A$. hydrophila by breeding in high conductivity/geothermally influenced water.

\section{Questions}

(1997)

1. What is the relationship between toad breeding and water chemistry?

2. What is the relationship between bacterial density and water chemistry?

3. What is the relationship between bacterial density and water column depth?

4. Does water chemistry change with season?

5. Does bacterial density change with season?

6. What is the relationship between bacterial density and toad breeding?

(A summary of the results to these questions can be found in Table 1).

Finally, if we found low bacterial densities within our high conductivity study sites, we would conduct a series of laboratory investigations to determine if the components of the water are limiting bacterial growth.

\section{$\downarrow \quad$ METHODS}

\section{STUDY SPECIES}

The Boreal Toad (Bufo boreas boreas) is found throughout the western half of the North American continent, from southern Alaska south to northern New Mexico in the Rocky Mountains (Stebbins 1995). The boreal toad is widely distributed throughout both Yellowstone and Grand Teton National Parks, from the lowest elevations in both parks up to $2865 \mathrm{~m}$ (9400 ft) near Togwotee Pass (historically) (Koch and Peterson 1995). A previously common and widespread species, the Boreal Toad appears to have declined in both distribution and abundance over much of its range in the Western United States, including the Greater 
Yellowstone Ecosystem. In Colorado, eastern Wyoming, and eastern Utah, this toad species could no longer be found at $85 \%$ of the sites in which it historically occurred (Corn et al. 1989).

\section{STUDY SITES}

Over the past six years, about fifteen to twenty Boreal Toad breeding sites have been identified within the GYE. During the summer of 1997, we sampled 12 breeding and 15 non-breeding sites (Table 2, Figure 1). We originally planned to sample an equal number of breeding and nonbreeding sites, but flooding during the spring of 1997, along with other factors, prevented this. The sampled toad breeding sites are located throughout the GYE. For each sampled breeding site, we selected a nearby amphibian site where toad breeding has not been detected. Some of the nearby amphibian sites were also chosen because toad breeding occurred there historically and is no longer occurring at that location. This sampling design allowed us to compare the water chemistry between known toad breeding sites to other amphibian sites where toad breeding does not occur.

\section{SAMPLING SCHEDULE}

We sampled the selected breeding and nonbreeding sites at least once during the 1997 field season. We sampled a subset of eleven sites (five breeding and six non-breeding) additional times during the months of July and August. Eight of these sites were sampled two additional times and three sites were sampled one additional time. We collected these additional samples from the same location within each site that the initial samples were taken. This sampling scheme allowed us to observe differences in water chemistry and bacterial densities between breeding and non-breeding sites, and also allowed us to observe changes in bacterial density and water chemistry over the course of a breeding season.

\section{WATER SAMPLES}

Water samples for determining bacterial densities were collected using sterile, individually wrapped, $120 \mathrm{ml}$ polypropylene bottles. We collected three water samples near observed amphibian egg masses (if present) or where breeding activity is known to occur based on past observations. Samples were collected just below the water surface, from the middle of the water column, and just above the bottom sediment. We used these samples to determine the mean bacterial density for each sampling site. Water samples were collected by first submerging the bottle and then removing the lid. Once the bottle was filled, the lid was replaced and the bottle was removed from the water column.

We collected two additional water samples to be used for chemical analysis from the same location within each study site that the samples were collected for determining bacterial densities. We stored these samples in $250 \mathrm{ml}$ and $500 \mathrm{ml}$ polypropylene bottles at $4^{\circ} \mathrm{C}$ until sending them off for chemical analysis. The water samples stored in the $250 \mathrm{ml}$ bottles were analyzed for alkalinity, ammonia, chloride, nitrate, sulfate, and total phosphorus. The water samples stored in the $500 \mathrm{ml}$ bottles were analyzed for calcium, potassium, lead, magnesium, silica, aluminum, and sodium.

\section{WATER CHEMISTRY}

Water chemistry analyses were performed for samples from each study site. In the field, we used a Solomat portable $\mathrm{pH}$, temperature, and conductivity meter (MPM 2000, Solomat Corporation, Connecticut) to determine $\mathrm{pH}$, temperature, and conductivity at each sampling site. Unfiltered water samples $(250 \mathrm{ml}$ bottle) were collected and stored at $4^{\circ} \mathrm{C}$ until they were taken to the Enviro $\mathrm{H}_{2} \mathrm{O}$ Lab, Pocatello Idaho. Unfiltered samples were analyzed for alkalinity, ammonia, chloride, nitrate, sulfate and total phosphorus. All samples were analyzed within two weeks of being collected following standard methods (APHA, 1995). Filtered water samples $(500 \mathrm{ml})$ were preserved with $1 \mathrm{ml}$ of nitric acid and stored at $4^{\circ} \mathrm{C}$ until taken to the Laboratory for Environmental Geochemistry, Idaho State University, Pocatello Idaho. Bottles used here were washed with nitric acid and rinsed with deionized water prior to sample collection. Filtered samples were analyzed for the following components: calcium, potassium, lead, magnesium, silica, aluminum, and sodium. All samples were analyzed within six months of being collected following standard methods (APHA, 1995).

\section{ISOLATION AND QUANTIFICATION OF Aeromonas hydrophila}

Approximately $200 \mu \mathrm{l}$ of each water sample was placed directly onto a plate of Rimler Shotts medium (specifically designed for isolation of $A$. 
hydrophila (Shotts and Rimler 1973)) with a micropipetter. We spread this water evenly over the agar surface using an L-shaped rod and turntable. An additional $30 \mathrm{ml}$ from each sample was filtered using a millipore filtering apparatus.

Bacteria were captured on a $0.45 \mu \mathrm{m}$ filter with a grid printed on the surface. We placed these filtered disks on the surface of an additional Rimler Shotts agar plate. The two inoculated plates from each sample were placed in a $37^{\circ} \mathrm{C}$ incubator for 20 24 hours. After the incubation period, we counted bacterial colonies that appeared yellow (presumptive for A. hydrophila). From the number of bacterial colonies counted, we determined the colony forming units (CFU's) which is the number of bacteria/ml of water.

\section{DATA ANALYSIS}

We entered all our data into a spreadsheet program (Microsoft Excel) and then transferred it into SPSS for Windows 7.0 (SPSS Inc., Chicago IL.) or SYSTAT 6.0 student version (SPSS Inc., Chicago IL.).

To determine which "general" factor(s) are correlated with breeding we ran a backwards stepwise logistic regression with conductivity, alkalinity, $\mathrm{pH}$, and temperature. Only those factors with significance levels of 0.05 or less were kept after each step. Prior to statistical analysis, conductivity and alkalinity were log transformed to avoid possible problems with curvelinearity. To test for curvelinearity we initially ran a backwards stepwise logistic regression without transforming any of the variables. The $-2 \log$ likelihood values obtained from the logistic regression can be used to assess how well the model fit the data and if the relationships between data and the binary response variable were possibly curvelinear (Ramsey and Schafer 1997). Smaller -2 log likelihood values indicate the logistic regression model fit the data better and that the binary response variables are more likely to be related to the explanatory variables by a direct linear relationship, which is an assumption of the logistic regression model (Ramsey and Schafer). The backwards stepwise logistic regression, without any of the variables transformed, revealed a $-2 \log$ likelihood value of 27.529. After log transforming both conductivity and alkalinity, we ran the logistic regression again. The -2 log likelihood value for this logistic regression was 25.334. This suggested that by log transforming both conductivity and alkalinity the model fit the data better. This also suggests that the relationship of breeding and non-breeding to conductivity and alkalinity was curvelinear. Therefore, we ran the backwards stepwise logistic regression with alkalinity and conductivity log transformed.

Once the "general" factor(s) correlated with toad breeding were determined, we ran a logistic regression on the water chemistry variables known to be associated with the "general" water chemistry measurement(s). Not all of the water chemistry measurements were included in this analysis due to the concentrations of some of the variables in solution being below the detection limit of the analytical procedures. If the water chemistry variable(s) could not be detected by the analytical procedure(s) at a minimum of fifty percent of the study sites, they were removed from the analysis. Nitrate, ammonia, chloride, total phosphorus, aluminum, and lead were excluded from this and subsequent analyses because the concentrations of these ions were below the detection limit of the analytical procedure at over half the study sites. This left sulfate, silica, magnesium, calcium, and sodium as the only water chemistry variables included in these analyses. Any values included in the analyses that were still less than the detection limit of the analytical procedure were given a conservative estimate (e.g, $<10 \mathrm{mg} / 1$ was estimated to be $9.9 \mathrm{mg} / \mathrm{l}$ ) in order to perform the statistical procedures.

To determine if the "general" factor(s) were highly correlated with mean CFU, we ran a backwards stepwise multiple regression on conductivity, alkalinity, $\mathrm{pH}$, and temperature. Only those values with a significance level of 0.05 or less were kept after each step. Prior to statistical analysis, conductivity and mean CFU were log transformed to obtain normality. Temperature and alkalinity met the normality assumptions and were entered into the analysis without transformation. Values of $\mathrm{pH}$ were converted to hydrogen ion concentrations prior to analysis and each hydrogen ion concentration was multiplied by $10^{7}$ to be recognized by SPSS. Once the "general" factor(s) highly correlated with mean CFU were determined, we ran a multiple regression analysis with the water chemistry variables known to be associated with these "general" water chemistry measurement(s). Prior to statistical analyses, chloride, silica, magnesium, sodium, potassium, and calcium were each $\log (x+1)$ transformed to obtain normality. 
To determine the relationship between bacterial density and water column depth we used block design analysis of variance. Mean CFU values were $\log$ transformed to obtain normality prior to statistical analysis.

To determine whether bacterial density, temperature, $\mathrm{pH}$, and conductivity vary significantly over the course of a breeding season, we used a repeated measures analysis of variance. Temperature met the assumptions of normality but, prior to statistical analysis, conductivity and mean CFU values were log transformed to obtain normality. Values of $\mathrm{pH}$ were converted to hydrogen ion concentrations prior to analysis and each hydrogen ion concentration was multiplied by $10^{7}$ to be recognized by SPSS. The GeisserGreenhouse Correction was used for the repeated measures analysis of variance with $\mathrm{pH}$ to correct for unequal variance. Mean $\mathrm{pH}$ values were calculated by taking the $\log$ of the mean hydrogen ion concentration.

Finally, to determine the relationship between toad breeding and bacterial density, we used a group comparison $\mathrm{T}$ test. Prior to statistical analysis, the mean CFU values were log transformed to obtain normality for the breeding and non-breeding sites.

\section{$\downarrow \quad$ RESULTS}

A summary of the results for each question can be found in Table 1 .

\section{Question 1- What is the relationship between toad breeding and water chemistry?}

The majority of the Boreal Toad breeding sites, sampled within the Greater Yellowstone Ecosystem, had measurements of conductivity that were significantly higher than non-breeding sites. From the results of the backwards stepwise logistic regression we found that conductivity was the only variable that produced a significant model (Table 3). For each log unit increase in conductivity, the likelihood of a study site being a toad breeding site increased by a factor of 5.89 . The approximate $95 \%$ confidence interval for this log likelihood ratio is 1.24 to 27.95 . Toad breeding and non-breeding group membership as explained by conductivity is shown in Figure 2. This final model correctly classified $66.7 \%$ of the breeding sites and $86.7 \%$ of the non-breeding sites sampled during the 1997 field season.

Because conductivity is an indicator of the total number of ions in solution, we ran another logistic regression using only calcium, magnesium, potassium, sodium, silica, and sulfate as independent variables. We found that silica $(\mathrm{Si})$ was the only variable remaining in the final model. For each unit increase in $\mathrm{Si}$, the likelihood of a study site being a toad breeding site increased by a factor of 1.08 . The $95 \%$ confidence interval for this $\log$ likelihood ratio is 0.96 to 1.23 . This final model correctly classified only $33.3 \%$ of the breeding sites and $86.7 \%$ of the non-breeding sites sampled during the 1997 field season.

Question 2- What is the relationship between bacterial density and water chemistry?

We found that alkalinity, $\mathrm{pH}$, and temperature were strongly and positively related to mean bacterial density. The results from the backwards stepwise multiple regression can be found in Table 4. Figure 3 shows the relationship between bacterial density and alkalinity and Figure 4 shows the relationship between bacterial density and conductivity.

Because alkalinity, $\mathrm{pH}$ and temperature were strongly related to mean $\mathrm{CFU}$, we ran another multiple regression using $\mathrm{pH}$, temperature and the two water chemistry variables most associated with alkalinity, calcium and magnesium. We found that all four contributed significantly and were each well below the cutoff to be removed in a stepwise fashion (Table 5). Therefore, this final model contains temperature, $\mathrm{pH}$, calcium, and magnesium.

Question 3 - What is the relationship between bacterial density and water column depth?

Because developing toad tadpoles are commonly found at or near the bottom of freshwater habitats, we needed to determine if densities of Aeromonas hydrophila vary with water column depth. We found that the various levels of water column sampling had no effect on the density of bacteria measured. The water column samples collected from all the study sites revealed a median of $35 \mathrm{bacteria} / \mathrm{ml}$ with a range of 0 to 2630 just below the water surface, a median of 40 bacterial $/ \mathrm{ml}$ with a range of 3 to 2760 from the middle of the water column, and a median of 25 
bacteria/ml with a range of 0 to 2845 just above the bottom sediment. The lognormal bacterial densities were tested against each other and the calculated Fratio was 0.321 with a probability of 0.727 .

\section{with season?}

\section{Question 4 - Does water chemistry change}

Because Boreal Toads are known to breed anytime from May to July (Koch and Peterson 1995) and even as late a August within the GYE (C.R. Peterson, unpublished data), we needed to determine if bacterial densities, water chemistry, and temperature varied significantly over the course of a single breeding season (May/June, July, August).

We found that the mean on-site temperature measurements for the four breeding and four non-breeding sites were not significantly different with respect to the time of year that the measurements were taken. The results for the repeated measures ANOVA can be found in Table 6 . These results also indicate the four breeding and four non-breeding sites cannot be distinguished from each other by taking temperature measurements from the water. The mean on-site temperature measured for the four breeding sites sampled two additional times was $21.5^{\circ} \mathrm{C} \pm 7.32$ SD in May/June, $20.5 \pm 7.90^{\circ} \mathrm{C}$ in July, and 24.05 $+4.44{ }^{\circ} \mathrm{C}$ in August. For the four non-breeding sites the mean on-site temperature was $17.1 \pm 7.49$ ${ }^{\circ} \mathrm{C}$ in May/June, $20.3 \pm 1.41{ }^{\circ} \mathrm{C}$ in July, and $17.9 \pm$ $2.46{ }^{\circ} \mathrm{C}$ in August. The comparisons in temperature between the breeding and non-breeding sites during the May/June and August sampling period suggest a possible difference; however, the differences were not statistically significant.

Measurements of $\mathrm{pH}$ did not significantly vary over the breeding season within the four breeding and non-breeding sites. The results for the repeated measures ANOVA with $\mathrm{pH}$ can be found in Table 7. The mean $\mathrm{pH}$ value for the four breeding sites sampled two additional times was 8.60 in May/June, 7.80 in July, and 8.95 in August. For the four non-breeding sites the mean $\mathrm{pH}$ value was 6.83 in May/June, 7.62 in July, and 8.26 in August.

Measurements of conductivity did vary significantly over the breeding season within the four breeding and four non-breeding sites. The results for the repeated measures ANOVA with conductivity can be found in Table 8 . However, a Tukey test was unable to reveal the source of those differences (Table 9). The results also indicate that the four breeding and four non-breeding sites cannot be distinguished from each other by taking conductivity measurements of the water. A graphical representation of the results can be found in Figure 5. For the four breeding sites sampled two additional times, the median conductivity value was $339 \mu \mathrm{s} / \mathrm{cm}$ with a range of 28.7 to 1071 in May/June, $432 \mu \mathrm{s} / \mathrm{cm}$ with a range of 76.6 to 1445 in July, and $431 \mu \mathrm{s} / \mathrm{cm}$ with a range of 90.3 to 1264 in August. For the four non-breeding sites the median conductivity value was $42.6 \mu \mathrm{s} / \mathrm{cm}$ with a range of 15.9 to 138 in May/June, $58.2 \mu \mathrm{s} / \mathrm{cm}$ with a range of 20.8 to 206 in July, and $52.4 \mu \mathrm{s} / \mathrm{cm}$ with a range of 15.0 to 228 in August.

with season?

Question 5 - Does bacterial density change

Densities of Aeromonas hydrophila did not significantly vary over the breeding season within the four breeding and four non-breeding sites. The results for the repeated measures ANOVA with bacterial density can be found in Table 10 . However, it should be noted that bacterial densities at the South Entrance stream, below the horse corral, were measured at 273 bacteria/ml during June, increased to $2803 \mathrm{bacteria} / \mathrm{ml}$ during July, and decreased to $60 \mathrm{bacteria} / \mathrm{ml}$ during August. The results also indicate that the four breeding and four non-breeding sites cannot be distinguished from each other by taking measurements of bacterial density from the water. For the four breeding sites sampled two additional times, the median bacterial density was 83 bacteria $/ \mathrm{ml}$ with a range of 15 to 2700 during May/June, 828 bacteria/ml with a range of 35 to 2803 during July, and $51 \mathrm{bacteria} / \mathrm{ml}$ with a range of 10 to 427 during August. For the four non-breeding sites the median bacterial density was $13 \mathrm{bacteria} / \mathrm{ml}$ with a range of 3 to 92 during May/June, 28 bacteria/ml with a range of 7 to 47 during July, and 18 bacteria/ml with a range of 8 to 105 during August.

Question 6 - What is the relationship between bacterial density and toad breeding?

Given that the occurrence of toad breeding is associated with high conductivity, and that densities of Aeromonas hydrophila increase with conductivity and alkalinity, we wanted to determine 
if the occurrence of toad breeding is associated with bacterial density. The water samples collected for determining bacterial density at each study site revealed a median of about $83 \mathrm{bacteria} / \mathrm{ml}$ with a range of 20 to 2700 for all the breeding sites and a median of about $33 \mathrm{bacteria} / \mathrm{ml}$ with a range of 3 to 2723 for all the non-breeding sites. The lognormal bacterial densities were tested against each other and the resulting $\mathrm{T}$ value was 1.735 with a probability of 0.095 . This indicates that the mean bacterial density measured at the toad breeding sites was not significantly different from the mean bacterial density measured at the non-breeding sites. However, it should be noted that Nez Perce Pond, a high conductivity $(1185 \mu \mathrm{s} / \mathrm{cm})$ non-breeding site, had a density of $2723 \mathrm{bacteria} / \mathrm{ml}$. The next highest bacterial density measured at a non-breeding site was 128 bacterial $/ \mathrm{ml}$ at pond 25 . This is a difference of over $2500 \mathrm{bacteria} / \mathrm{ml}$. If Nez Perce Pond is removed from the analysis, the median bacterial density is reduced from 33 bacteria $/ \mathrm{ml}$ to $29 \mathrm{bacterial} / \mathrm{ml}$ with a range of 3 to 126 for the non-breeding sites. The resulting $\mathrm{T}$ is 1.586 with a probability of 0.024 , indicating a significant difference.

\section{$\downarrow \quad$ DISCUSSION}

During the past forty years, Boreal Toads appear to have declined in abundance and distribution throughout much of the Greater Yellowstone Ecosystem (Peterson et al. 1992). The results of this study demonstrate that the remaining Boreal Toad breeding sites, located within the GYE, can be distinguished from non-breeding sites by examining the conductivity of the water. This observed difference in conductivity between toad breeding and non-breeding sites is similar to observations made during the 1991 field season (Peterson et. al. 1992). Conductivity correctly classified $67 \%$ of the breeding sites (eight of twelve) sampled during 1997 with an overall accuracy of $78 \%$. Each log unit increase in conductivity increased the likelihood of a study site being a toad breeding site by a factor of 5.89 . The only ion found to be significantly different between breeding and non-breeding sites in this study was silica. However, silica had a confidence interval around its odds ratio of 0.96 to 1.23 and could only correctly classify $33.3 \%$ of the breeding sites. Therefore, even though silica was the only variable remaining in the second logistic regression model, conductivity is a better predictor of toad breeding.
The logistic regression model with conductivity did not correctly classify four of the twelve toad breeding sites sampled during 1997. However, it should be noted that toad breeding could not be verified at McReynolds Reservoir $(32.8 \mu \mathrm{s} / \mathrm{cm})$ even though the breeding activities of Boreal Toads were detected at this study site in the early 1990's. The majority of the Boreal Toad tadpoles at the South Entrance stream below the horse corral $(28.7 \mu \mathrm{s} / \mathrm{cm})$ perished prior to metamorphosis due to infection and a substantial portion of the toad tadpoles at Pond $26(152 \mu \mathrm{s} / \mathrm{cm})$ perished shortly after hatching. This left Stamp Meadows, located on the Targhee National Forest, as the only low conductivity study site where Boreal Toads are known to breed successfully. Because three of the four toad breeding sites not correctly classified by the conductivity model had low tadpole survivorship, it may be more appropriate to label the eight toad breeding sites correctly classified by the conductivity model as successful breeding sites.

Unfortunately, measurements of water chemistry at toad breeding sites from over forty years ago were not taken. These data would have been useful in determining whether Boreal Toad breeding sites have always been associated with high conductivity within the GYE. However, we do know that Boreal Toads historically bred at Lower Moose Pond within Grand Teton National Park, and near Togwotee Pass within Bridger Teton National Forest (Carpenter 1953, and field notes). Boreal Toads were not detected at these two sites during the 1991 field season (Peterson et. al. 1992) or during the current study. During 1997, the level of conductivity measured at Lower Moose Pond was $15.9 \mu \mathrm{s} / \mathrm{cm}$ and the level of conductivity measured at Togwotee Pass Pond was $41.5 \mu \mathrm{s} / \mathrm{cm}$. Both of these sites have levels of conductivity that are substantially lower than most of the Boreal Toad breeding sites sampled during 1997 (Figure 2). At present, we can only speculate as to whether Boreal Toads have only declined and disappeared from areas with low conductivity.

We isolated and determined the concentration of $A$. hydrophila in the water for each of our study sites during 1997 because redleg has been implicated in Boreal Toad declines elsewhere (Carey 1993). Interestingly, a negative correlation between conductivity and densities of $A$. hydrophila in freshwater environments has been described (Hazen et al. 1978). From the results of our study, 
we found $A$. hydrophila to be positively correlated with conductivity (Figure 4), and found that alkalinity, $\mathrm{pH}$ and temperature $\left({ }^{\circ} \mathrm{C}\right)$ significantly predicted bacterial density just as well as temperature, $\mathrm{pH}$, alkalinity, and conductivity combined. This observation is just the opposite of what we expected. Based on a previous study (1978), we predicted low bacterial densities within our high conductivity breeding sites. Therefore, we rejected our original hypothesis that Boreal Toads might be protected from redleg by breeding in water with very low densities of bacteria and that the low bacterial densities might reduce the risk of infection and outbreak of disease.

Because densities of $A$. hydrophila were positively correlated with conductivity, we needed to generate alternate hypotheses for how Boreal Toads could be protected from redleg within these high conductivity sites. One hypothesis is that the unusual water chemistry from the toad breeding sites may not allow $A$. hydrophila to "turn on" the virulence factors needed to successfully infect a host, even when an individual is immunocompromised. Another hypothesis is that protection from redleg could be a product of the breeding sites being geothermally influenced. Sites which are geothermally influenced may maintain continuously higher temperatures than non-thermal sites and be less susceptible rapid changes in temperature. This could potentially reduce cold shock as an environmental stressor within these areas.

Because Boreal Toad tadpoles are commonly found at or near the bottom of freshwater habitats, we needed to determine if bacterial densities vary consistently with water column depth. We found that densities $A$. hydrophila did not consistently vary with depth among all the breeding and non-breeding sites. If we had found densities of $A$. hydrophila to be consistently higher at a given depth among all the study sites, we would have needed to consider this when deciding the level of bacteria to use for our infection studies in 1998.

During 1997 we found that densities of Aeromonas hydrophila did not significantly vary over the breeding season within the four breeding and non-breeding sites sampled two additional times. However, it is worth noting that the mean bacterial densities for the South Entrance stream below the horse corral were measured at 273 bacteria/ml in June, increased to $2803 \mathrm{bacteria} / \mathrm{ml}$ in July, and decreased to 60 bacteria/ml during August. The South Entrance stream below the horse corral is the only breeding site currently found in Yellowstone with conductivity measurements below $100 \mu \mathrm{s} / \mathrm{cm}$. The bacterial densities observed at this site in July are similar to the bacterial densities measured at study sites (breeding and non-breeding) with conductivity measurements greater than $400 \mu$ $\mathrm{s} / \mathrm{cm}$. While sampling this study site in July, we observed approximately forty dead and decaying tadpoles. Some of these tadpoles could be identified as Bufo boreas, where others were identified as Columbia Spotted Frog (Rana luteiventris). The week prior to sampling this site in July, adult spotted frogs were apparently observed exhibiting symptoms similar to redleg (Debra Patla, personal communicaton). It is unknown whether $A$. hydrophila was responsible for this observed die-off in tadpoles and adult spotted frogs, because no swabs of the decaying tadpoles were taken due to the high probability of the causative agent being hidden by the growth of saprophytic fungi and bacteria. Also of interest, the temperature of the water at the time the dead tadpoles were found was $10.7{ }^{\circ} \mathrm{C}$. Because the immune systems of ectothermic animals are apparently temperature dependent, (Kluger 1979), this "cooler" water temperature may have suppressed the ability of the tadpoles immune systems to function properly and led to some type of infection, and ultimately death.

Given that the majority the known Boreal Toad breeding sites in the GYE occur in areas with high conductivity and that densities of $A$. hydrophila were found to be positively correlated with conductivity, one might expect bacterial densities to be correlated with the occurrence of toad breeding. The results from this study found no significant difference in bacterial density between breeding and non-breeding sites. However, most of the observed variation in bacterial density for the non-breeding sites was driven by a high conductivity site known as Nez Perce Pond. This study site actually increased the mean bacterial density measured for the non-breeding sites by $178.6 \mathrm{bacteria} / \mathrm{ml}$, and indicates that the levels of bacteria measured are more correlated with the chemical and physical (i.e., temperature) components of the water than with the presence of toad breeding.

In summary, the results of this study verified that the remaining Boreal Toad breeding sites found in the Greater Yellowstone Ecosystem are predominantly found in areas with high 
conductivity in comparison to historical sites where toad breeding no longer occurs and other amphibian breeding sites where toad breeding has not been detected. Densities of Aeromonas hydrophila, a causative agent of redleg, were found to be positively correlated with conductivity, alkalinity, $\mathrm{pH}$ and temperature and are opposite than what we predicted. Because toad breeding has been shown to be associated with conductivity and densities of Aeromonas hydrophila increased with conductivity, we will test the effects of conductivity and bacterial density on the susceptibility of tadpoles to infection during 1998. We also plan to test the effect of temperature on the susceptibility of toad tadpoles to infection because many of the Boreal Toad breeding sites found in the GYE are also geothermally influenced.

\section{$\downarrow \quad$ ACKNOWLEDGEMENTS}

Direct funding for travel expenses, materials, water chemistry analyses, and housing at the AMK ranch was supplied by the University of Wyoming - National Park Service Research Center, Grand Teton National Park, and the National Fish and Wildlife Foundation. The University of Wyoming also provided an incubator, refrigerator and laboratory space at the AMK ranch. Idaho State University supplied a millipore filtering apparatus and additional instruments necessary for isolating and quantifying bacteria. Debra Patla, Raymond Clark, and Stephen Burton assisted in the location of study sites in Yellowstone National Park, Grand Teton National Park, Targhee National Forest, Bridger Teton National Forest, or Caribou National Forest. Rick Mossmann transported Debra Patla and Jeremy Hawk by canoe to the study sites located across the Snake River near the South Entrance to Yellowstone National Park. The Laboratory for Environmental Geochemistry, Idaho State University, supplied us with water bottles and a portable filtering apparatus to filter the water samples needed for chemical analysis. Mike McCurry provided advice on handling and storing water samples to be used for chemical analysis. Kathy Spiegel provided advice and expertise in the field of microbiology. Teri Peterson and Stephen Burton assisted in the selection and interpretation of the statistical procedures.

\section{LITERATURE CITED}

APHA. 1995. Standard Methods for the Examination of Water and Wastewater. American Public Health Association. Washington D.C.

Blaustein A.R., P.D. Hoffman, D.G. Hokit, J.M. Kiesecker, S.C. Walls, and J.B. Hays. 1994a. UV repair and resistance to solar UV-B in amphibian eggs: a link to population declines? Proceedings of the National Academy of Sciences of the United States of America 91:1791-1795

Blaustein A.R., D.G. Hokit, and R.K. O'Hara. 1994b. Pathogenic fungus contributes to amphibian losses in the Pacific Northwest. Biological Conservation 67:251-254

Blaustein, A.R., and D.B. Wake. 1990. Declining amphibian populations: A global phenomenon? Trends in Ecology and Evolution 5:203-4

Brodie, E.D., and D.R. Formanowicz. 1987. Antipredator mechanisms of larval anurans: protection of palatable individuals. Herpetologica 43(3):369-73

Carey, C. 1993. Hypothesis concerning the causes of the disappearance of Boreal Toads from the mountains of Colorado. Conservation Biology 7:355-62

Carpenter, C.C. 1953. An ecological survey of the herpetofauna of the Grand Teton-Jackson Hole area of Wyoming. Copeia 1953(3):170-74

Corn, P.S., and F.A. Vertucci. 1989. Descriptive risk assessment of the effects of acidic deposition on Rocky Mountain amphibians. Journal of Herpetology 26:361-69

Dusi, J.L. 1949. The natural occurrence of "Redleg," Pseudomonas hydrophila, in a population of toads, Bufo americanus. Ohio Journal of Science 49:70-71 
Emerson, H., and C. Norris. 1905. "Red-leg"-an infectious disease of frogs. The Journal of Experimental Medicine 7:32-58

Hazen, T.C., C.B. Fliermans., R.P. Hirsch., and G.W. Esch. 1978. Prevalence and distribution of Aeromonas hydrophila in the United States. Applied and Environmental Microbiology 36:731-38

Hird, D.W., S.L. Diesch., R.G. McKinnell., E. Gorham., F.B. Martin., S.W. Kurtz., and C. Dubrovolny. 1981. Aeromonas hydrophila in wild caught frogs and tadpoles (Rana pipens) in Minnesota. Laboratory Animal Science 31:166-69

Hunsaker, D., and F.E. Potter. 1960. "Red-leg" in natural populations of amphibians. Herpetologica 16: 285-86

Kluger, M.J. 1979. Fever in ectotherms: evolutionary implications. American Zoologist 19:295-304

Koch, E.D. and C.R. Peterson. 1995. The Amphibians and Reptiles of Yellowstone and Grand Teton National Parks. University of Utah Press, Salt Lake City, Utah. 188 pp.

Kulp, W.L., and D.G. Borden. 1942. Further studies on Proteus hydrophilus, the etiologic agent in "Red-leg" disease of frogs. Journal of Bacteriology 44:673-85

Nyman, S. 1986. Mass mortality in larval Rana sylvatica attributable to the bacterium, Aeromonas hydrophila. Journal of Herpetology 20:196-201

Pechmann, J.H., D.E. Scott., R.D. Semlitsch., J.P. Caldwell., L.J. Vitt., and J.W. Gibbons. 1991. Declining amphibian populations: The problem of separating human impacts from natural fluctuations. Science, NY. 253:892-5

Phillips, K. 1990. Where have all the frogs and toads gone? BioScience. 40:422-4
Peterson, C.R., E.D. Koch., S.P. Corn. 1992. Monitoring amphibian populations in Yellowstone and Grand Teton national parks. Final report to the UW-NPS Research Center

Ramsey, F., and D. Schafer. 1997. Statistical Sleuth. Duxbury Press. pp 564-98

Reed, B.B., and G.C. Toner. 1942. Proteus hydrophilus infections in pike, trout and frogs. Canadian Journal of Research 20D:161-165

Russell, F.H. 1898. An epidemic, septicemic disease among frogs due to the Bacillus hydrophilus fuscus. Journal of the American Medical Association 30:1442-49

Shotts, E.M., and R. Rimler. 1973. Medium for the Isolation of Aeromonas hydrophila. Applied Microbiology 26:550-53

Stebbins, R.C., and N.W. Cohen. 1995. A Natural History of Amphibians. Princeton University Press pp. 210-13

U.S. Fish and Wildlife Service. 1995. Endangered and threatened wildlife and plants; 12month finding for a petition to list the southern Rocky Mountain population of the boreal toad as endangered. Pages 1528115283 in volume 60 (23 March) Federal Register. U.S. Government Printing Office, Washington, D.C. USA.

Wake, D.B. 1991. Declining amphibian populations. Science 253: 860

Wyman, R.L. 1990. Whats's happening to the amphibians? Conservation Biology 4:350-2 


\begin{tabular}{|c|c|c|c|c|c|c|}
\hline 菢 & 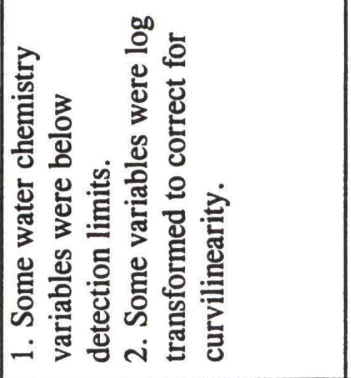 & 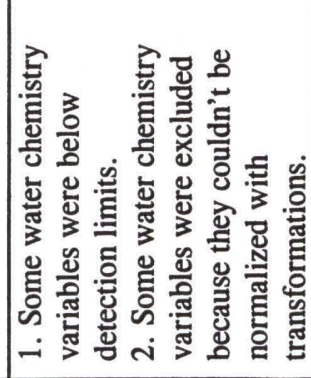 & 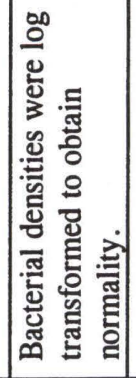 & 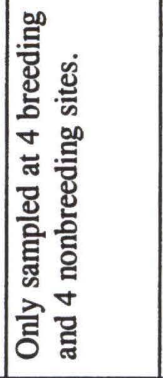 & 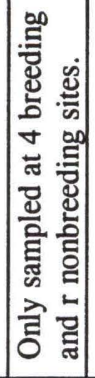 & 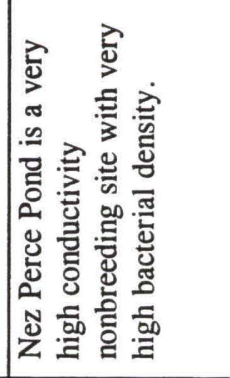 \\
\hline 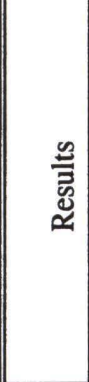 & 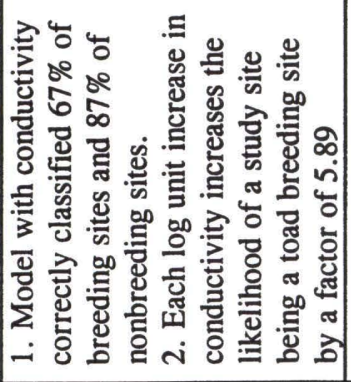 & 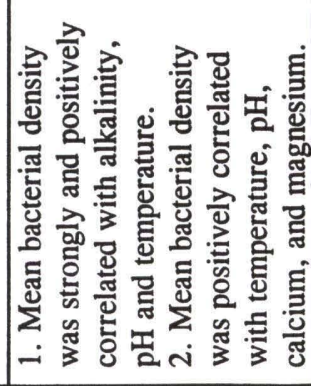 & 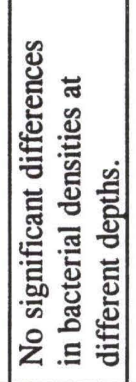 & 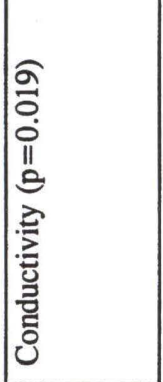 & 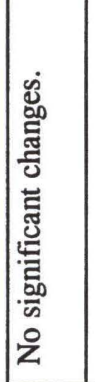 & 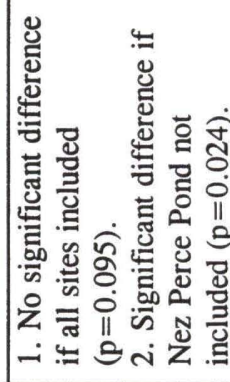 \\
\hline 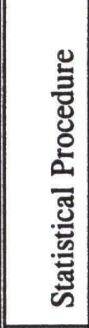 & 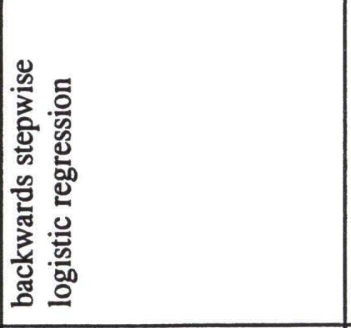 & 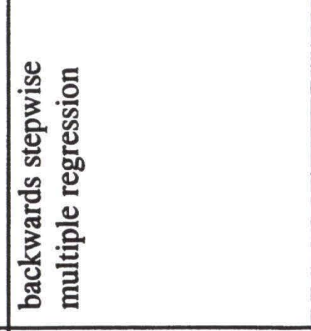 & 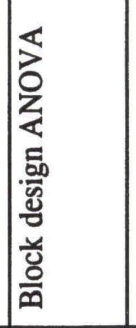 & 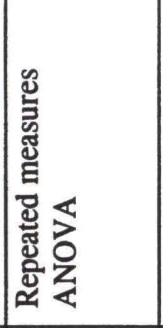 & 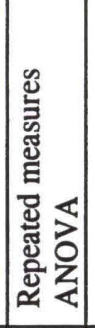 & 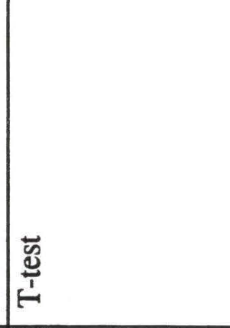 \\
\hline 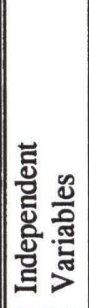 & 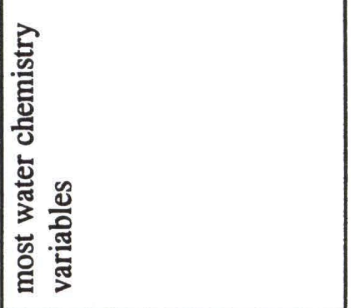 & 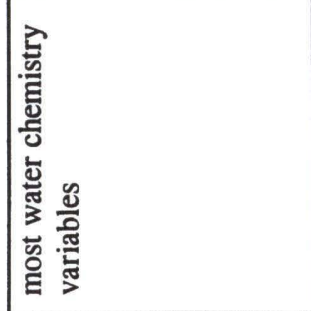 & 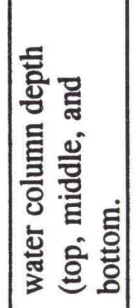 & 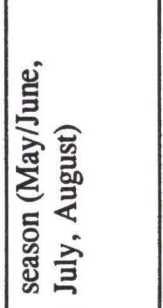 & 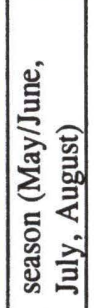 & 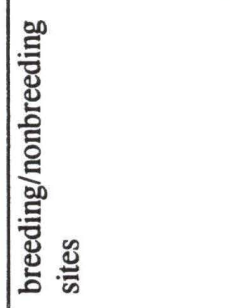 \\
\hline 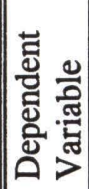 & 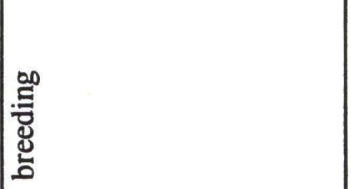 & 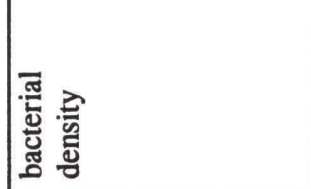 & 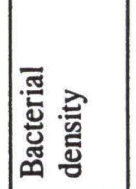 & 总 & 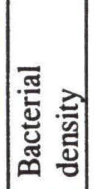 & 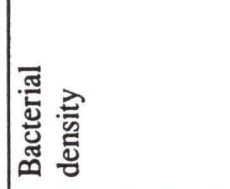 \\
\hline 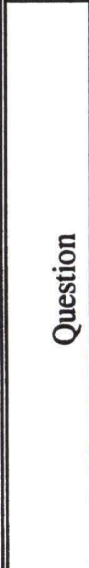 & 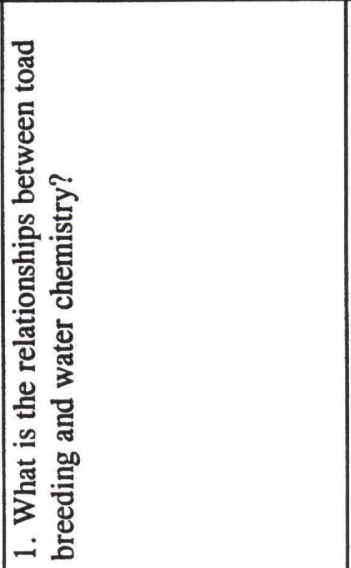 & 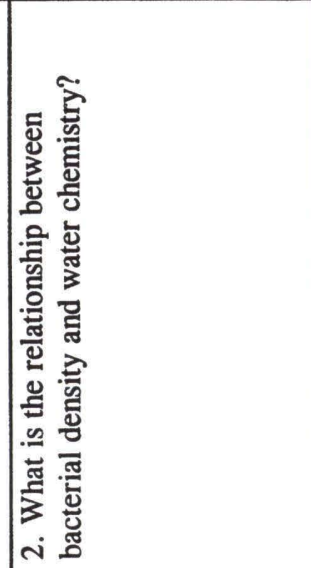 & 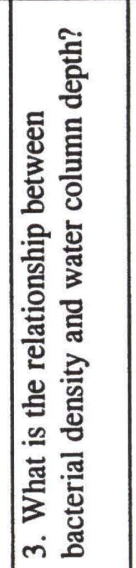 & 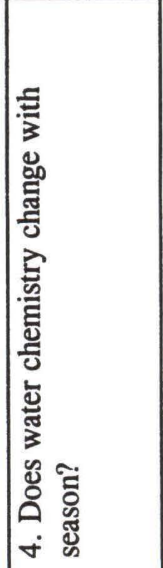 & 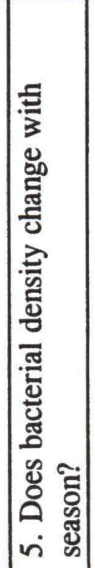 & 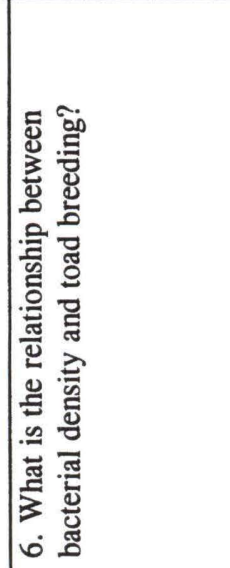 \\
\hline
\end{tabular}


Table 2. The location of study sites within the Greater Yellowstone Ecosystem sampled during 1997. The number of each study site corresponds to the numbers displayed on the map (Figure 1 ) and the circles on the map represent the study site location.

\begin{tabular}{|c|c|c|c|c|c|c|c|}
\hline Site & $\begin{array}{c}\text { Toad } \\
\text { Breeding } \\
\text { Site }\end{array}$ & $\begin{array}{c}\text { Yellowstone } \\
\text { National Park }\end{array}$ & $\begin{array}{l}\text { Grand Teton } \\
\text { National Park }\end{array}$ & $\begin{array}{c}\text { Targhee } \\
\text { National } \\
\text { Forest }\end{array}$ & \begin{tabular}{|c|} 
Bridger \\
Teton \\
National \\
Forest
\end{tabular} & $\begin{array}{c}\text { Caribou } \\
\text { National } \\
\text { Forest }\end{array}$ & Remarks \\
\hline 1. Slide Lake & no & $\mathrm{x}$ & & & & & \\
\hline 2. Slough Creek pond & no & $\mathrm{x}$ & & & & & \\
\hline 3. Indian pond & yes & $\mathbf{x}$ & & & & & Historical? \\
\hline 4. Lodge Creek - Pool 3 & no & $\mathbf{x}$ & & & & & \\
\hline 5. Lodge Creek Lagoon & no & $\mathbf{x}$ & & & & & \\
\hline 6. Harlequin Lake & no & $\mathbf{x}$ & & & & & \\
\hline 7. Paint Pot Toad Pool & yes & $\mathrm{x}$ & & & & & \\
\hline 8. Nex Perce Pond . & no & $\mathrm{x}$ & & & & & \\
\hline 9. Tangled Creek & yes & $\mathrm{x}$ & & & & & \\
\hline 10. South Entrance thermal stream & yes & $\mathrm{x}$ & & & & & \\
\hline 11. South Entrance vernal pond & yes & $\mathrm{x}$ & & & & & \\
\hline 12. South Entrance permanent pond & no & $\mathrm{x}$ & & & & & \\
\hline 13. South Entrance stream by corral & yes & $\mathrm{x}$ & & & & & \\
\hline 14. Pond 25 & no & $\mathbf{x}$ & & & & & \\
\hline 15. Pond 26 & yes & $\mathbf{x}$ & & & & & \\
\hline 16. Taggart Lake Outflow & no & & $\mathrm{x}$ & & & & \\
\hline 17. Lower Moose Pond & no & & $\mathrm{x}$ & & & & Historical toad site \\
\hline 18. Leigh Lake & no & & $\mathrm{x}$ & & & & \\
\hline 19. Ditch Creek & yes & & & & $\mathbf{x}$ & & \\
\hline 20. Togwotee Pass Pond & no & & & & $\mathbf{x}$ & & Historical toad breeding site \\
\hline 21. Blackrock Oxbow & yes & & & & $\mathrm{x}$ & & \\
\hline 22. Stamp Meadow & yes & & & $x$ & & & large ( $>50$ adult $)$ population \\
\hline 23. McReynolds Reservoir & yes & & & $\mathbf{x}$ & & & \\
\hline 24. Moose Creek Cattail Pond & no & & & $\mathrm{x}$ & & & \\
\hline 25. North Leigh Mill Pond & no & & & $\mathrm{x}$ & & & \\
\hline 26. Tin Cup Creek Oxbow & yes & & & & & $\mathrm{x}$ & \\
\hline 27. Tin Cup Creek Pond & no & & & & & $\mathrm{x}$ & \\
\hline
\end{tabular}


Table 3. Results for the backwards stepwise logistic regression of toad breeding verses temperature, conductivity, alkalinity, and $\mathrm{pH}$. Each model represents a single step where one of the variables was removed. The final model (4) contains only conductivity.

\begin{tabular}{|c|c|c|c|c|c|c|c|c|}
\hline Variable & Model & Coefficient & S.E. & Wald & $\mathrm{df}$ & Sig. & Odds Ratio & $95 \% \mathrm{CI}$ \\
\hline $\mathrm{pH}$ & \multirow{5}{*}{1} & \begin{tabular}{|l|}
1.0910 \\
\end{tabular} & 0.8425 & 1.6670 & 1 & 0.1953 & 2.9774 & $0.57-15.52$ \\
\hline Temperature & & -0.1674 & 0.1332 & 1.5788 & 1 & 0.2089 & 0.8459 & $0.65-1.09$ \\
\hline Conductivity $^{\dagger}$ & & 4.2460 & 2.6692 & 2.5305 & 1 & 0.1117 & 69.8279 & $0.37-13064$ \\
\hline Alkalinity $^{+}$ & & -4.7912 & 3.0802 & 2.4196 & 1 & 0.1198 & 0.0083 & $0.00002-3.48$ \\
\hline Constant & & -5.4548 & 5.2275 & 1.0889 & 1 & 0.2967 & & \\
\hline $\mathrm{pH}$ & \multirow{4}{*}{2} & 0.7388 & 0.7634 & 0.9366 & 1 & 0.3332 & 2.0934 & $0.47-9.34$ \\
\hline Conductivity ${ }^{\dagger}$ & & 2.8516 & 2.0976 & 1.8481 & 1 & 0.1740 & 17.3158 & $0.28-1056$ \\
\hline Alkalinity $^{\dagger}$ & & -2.6219 & 2.1501 & 1.4870 & 1 & 0.2227 & 0.0727 & $0.001-4.92$ \\
\hline Constant & & -6.8043 & 4.9464 & 1.8922 & 1 & 0.1689 & & \\
\hline Conductivity $^{\dagger}$ & \multirow{3}{*}{3} & 3.7829 & 1.8150 & 4.3439 & 1 & 0.0371 & 43.9418 & $4.30-448.3$ \\
\hline Alkalinity $^{\dagger}$ & & -2.9692 & 2.0521 & 2.0935 & 1 & 0.1479 & 0.0513 & $0.0009-2.87$ \\
\hline Constant & & -2.4219 & 2.0098 & 1.4520 & 1 & 0.2282 & & \\
\hline Conductivity $^{\dagger}$ & \multirow{2}{*}{4 (Final) } & 1.7727 & 0.7948 & 4.9740 & 1 & 0.0257 & 5.8867 & $1.24-27.95$ \\
\hline Constant & & -3.9623 & 1.7467 & 5.1458 & 1 & 0.233 & & \\
\hline
\end{tabular}

$t \log$ transformed variable

Table 4. Results for the backwards stepwise multiple regression of bacterial density verses temperature, alkalinity, $\mathrm{pH}$ and conductivity. Each model, beyond model 1, represents a step with one variable removed from the analysis.

\begin{tabular}{|c|c|c|c|c|c|c|c|c|}
\hline Variables & Model & $\begin{array}{l}\text { Sum of } \\
\text { Squares }\end{array}$ & $\mathrm{df}$ & $\begin{array}{l}\text { Mean } \\
\text { Square }\end{array}$ & R-square & $\begin{array}{l}\text { Adjusted } \\
\text { R Square }\end{array}$ & $\mathrm{F}$ & Sig \\
\hline Temperature, & 1 Regression & 11.070 & 4 & 2.762 & 0.589 & 0.514 & 7.885 & 0.00 \\
\hline Alkalinity, $\mathrm{pH}^{*}$, & Residual & 7.722 & 22 & 0.351 & & & & \\
\hline Conductivity $^{\dagger}$ & Total & 18.792 & 26 & & & & & \\
\hline & 2 Regression & 10.987 & 3 & 3.662 & 0.585 & 0.53 & 10.792 & 0.00 \\
\hline Temperature, & Residual & 7.805 & 23 & 0.339 & & & & \\
\hline Alkalinity, $\mathrm{pH}^{*}$ & Total & 18.792 & 26 & & & & & \\
\hline
\end{tabular}

* converted to hydrogen ion concentrations

t log transformed variable 
Table 5. Results for the backwards stepwise multiple regression of bacterial density verses temperature, magnesium, and calcium. Each variable was below the cutoff to be removed from the model. Therefore, the final model contains all three variables.

\begin{tabular}{|c|c|c|c|c|c|c|c|c|}
\hline Variables & Model & $\begin{array}{l}\text { Sum of } \\
\text { Squares }\end{array}$ & df & $\begin{array}{l}\text { Mean } \\
\text { Square }\end{array}$ & R Square & $\begin{array}{l}\text { Adjusted } \\
\text { R Square }\end{array}$ & $\mathrm{F}$ & Sig. \\
\hline Temperature & 1 Regression & 13.493 & 4 & 3.373 & 0.718 & 0.667 & 14.007 & 0.00 \\
\hline Magnesium $^{\dagger}$ & Residual & 5.298 & 22 & 0.241 & & & & \\
\hline $\begin{array}{l}\text { Calcium }^{\dagger} \\
\mathrm{pH}^{*}\end{array}$ & Total & 18.792 & 26 & & & & & \\
\hline
\end{tabular}

t log transformed variable.

* converted to hydrogen ion concentration

Table 6. Repeated measures analysis of variance for temperature. Breed represents the between effects and season represents the within effects.

\begin{tabular}{|l|c|c|c|c|c|}
\hline \multicolumn{1}{|c|}{ Source } & $\begin{array}{c}\text { Sum of } \\
\text { Squares }\end{array}$ & df & $\begin{array}{c}\text { Mean } \\
\text { Square }\end{array}$ & F & Sig. \\
\hline Breed & 77.042 & 1 & 77.042 & 1.516 & 0.264 \\
\hline Error & 304.958 & 6 & 50.826 & & \\
\hline Season & 11.523 & 2 & 5.762 & 0.235 & 0.794 \\
\hline Season*Breed & 37.403 & 2 & 18.702 & 0.762 & 0.488 \\
\hline Error & 294.367 & 12 & 24.531 & & \\
\hline
\end{tabular}

Table 7. Repeated measures analysis of variance for $\mathrm{pH}$. Breed represents the between effects and season represent the within effects.

The Giesser-Greenhouse Correction was used to adjust for unequal

Variance.

\begin{tabular}{|l|c|c|c|c|c|}
\hline \hline Source & $\begin{array}{c}\text { Sum of } \\
\text { Squares }\end{array}$ & df & Mean Square & F & Sig. \\
\hline Breed & 163.408 & 0.5325 & 306.864 & 4.376 & 0.13 \\
\hline Error & 224,075 & 3.195 & 70.133 & & \\
\hline Season & 222,625 & 1.065 & 209.022 & 3.971 & 0.089 \\
\hline Season*Breed & 254.435 & 1.065 & 238.888 & 4.548 & 0.073 \\
\hline Error & 336.403 & 6.39 & 52.641 & & \\
\hline
\end{tabular}


Table 8. Repeated measures analysis of variance for conductivity. Breed represents the between effects and season represents the within effects.

\begin{tabular}{|l|c|c|c|c|c|}
\hline \multicolumn{1}{|c|}{ Source } & $\begin{array}{c}\text { Sum of } \\
\text { Squares }\end{array}$ & df & $\begin{array}{c}\text { Mean } \\
\text { Square }\end{array}$ & F & Sig. \\
\hline Breed & 3.643 & 1 & 3.643 & 4.723 & 0.073 \\
\hline Error & 4.628 & 6 & 0.771 & & \\
\hline Season & 0.152 & 2 & $7.59 \mathrm{E}-02$ & 5.583 & 0.019 \\
\hline Season*Breed & $4.01 \mathrm{E}-03$ & 2 & $2.00 \mathrm{E}-03$ & 0.147 & 0.864 \\
\hline Error & 0.163 & 12 & $1.36 \mathrm{E}-02$ & & \\
\hline
\end{tabular}

Table 9. Tukey test for repeated measures analysis of variance for conductivity.

\begin{tabular}{|l|c|c|c|c|c|c|}
\hline source & Comparison & Difference & $\mathrm{SE}$ & $\mathrm{q}$ & $\mathrm{q}_{0.05,12,3}$ & Conclusion \\
\hline Within effects & May/June vs August & 0.123 & 0.058 & 2.11 & 3.77 & $\mu=\mu$ \\
(non-breeding) & May/June vs July & 0.175 & 0.058 & 3.00 & 3.77 & $\mu=\mu$ \\
& July vs August & 0.053 & 0.058 & 0.91 & 3.77 & $\mu=\mu$ \\
\hline Within effects & May/June vs August & 0.183 & 0.058 & 3.14 & 3.77 & $\mu=\mu$ \\
(breeding) & May/June vs July & 0.189 & 0.058 & 3.24 & 3.77 & $\mu=\mu$ \\
& July vs August & 0.005 & 0.058 & 0.086 & 3.77 & $\mu=\mu$ \\
\hline
\end{tabular}

Table 10. Repeated measures analysis of variance for bacterial density. Breed represents the between effects and season represents the within effects.

\begin{tabular}{|l|c|c|c|c|c|}
\hline \multicolumn{1}{|c|}{ Source } & $\begin{array}{c}\text { Sum of } \\
\text { Squares }\end{array}$ & df & $\begin{array}{c}\text { Mean } \\
\text { Square }\end{array}$ & F & Sig. \\
\hline Breed & 3.816 & 1 & 3.816 & 3.161 & 0.126 \\
\hline Error & 7.242 & 6 & 1.207 & & \\
\hline Season & 0.58 & 2 & 0.29 & 1.241 & 0.324 \\
\hline Season*Breed & 0.534 & 2 & 0.267 & 1.142 & 0.351 \\
\hline Error & 2.803 & 12 & 0.234 & & \\
\hline
\end{tabular}




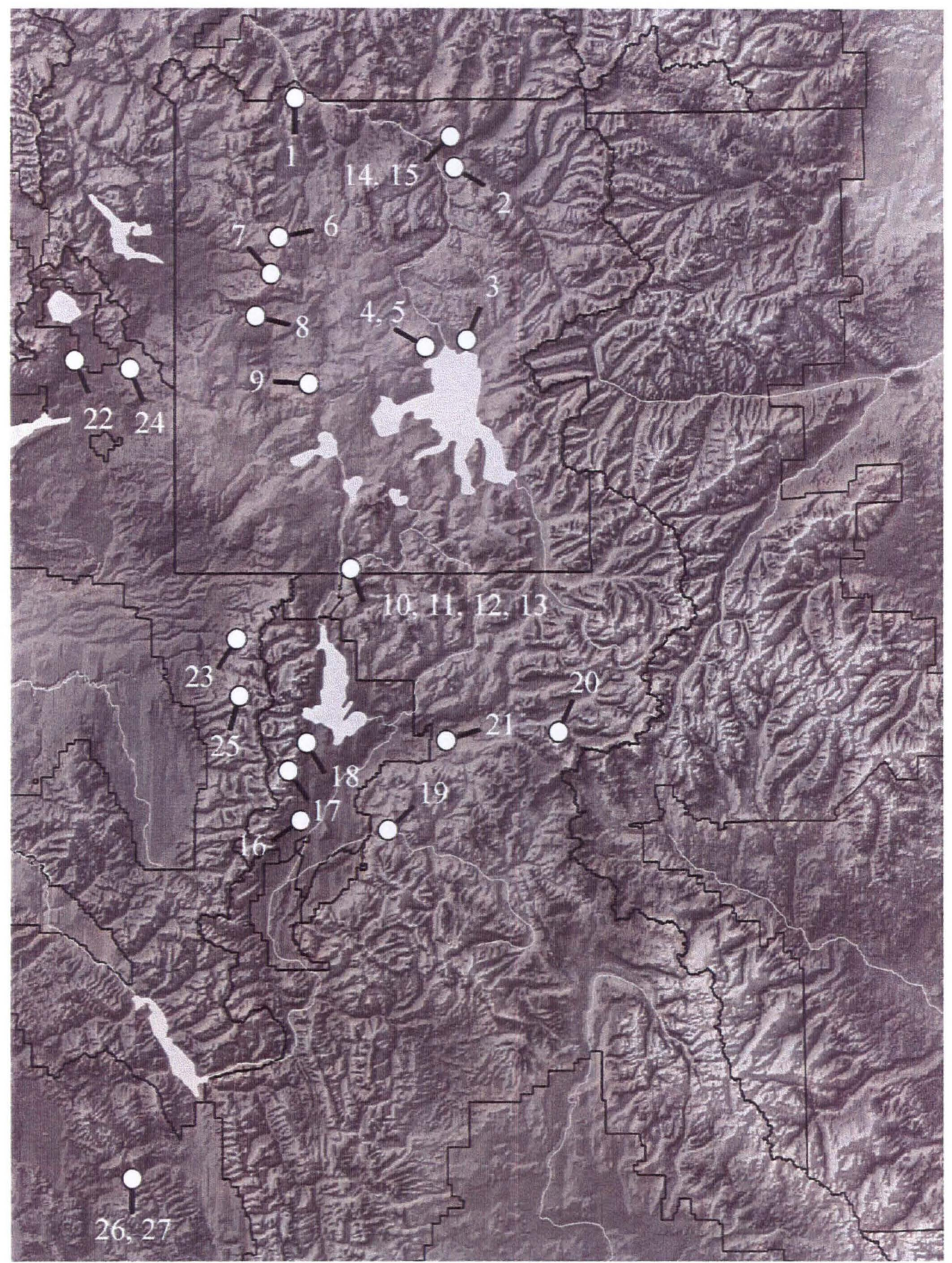

Figure 1. The location of 1997 sampling sites in the Greater Yellowstone Ecosystem. 


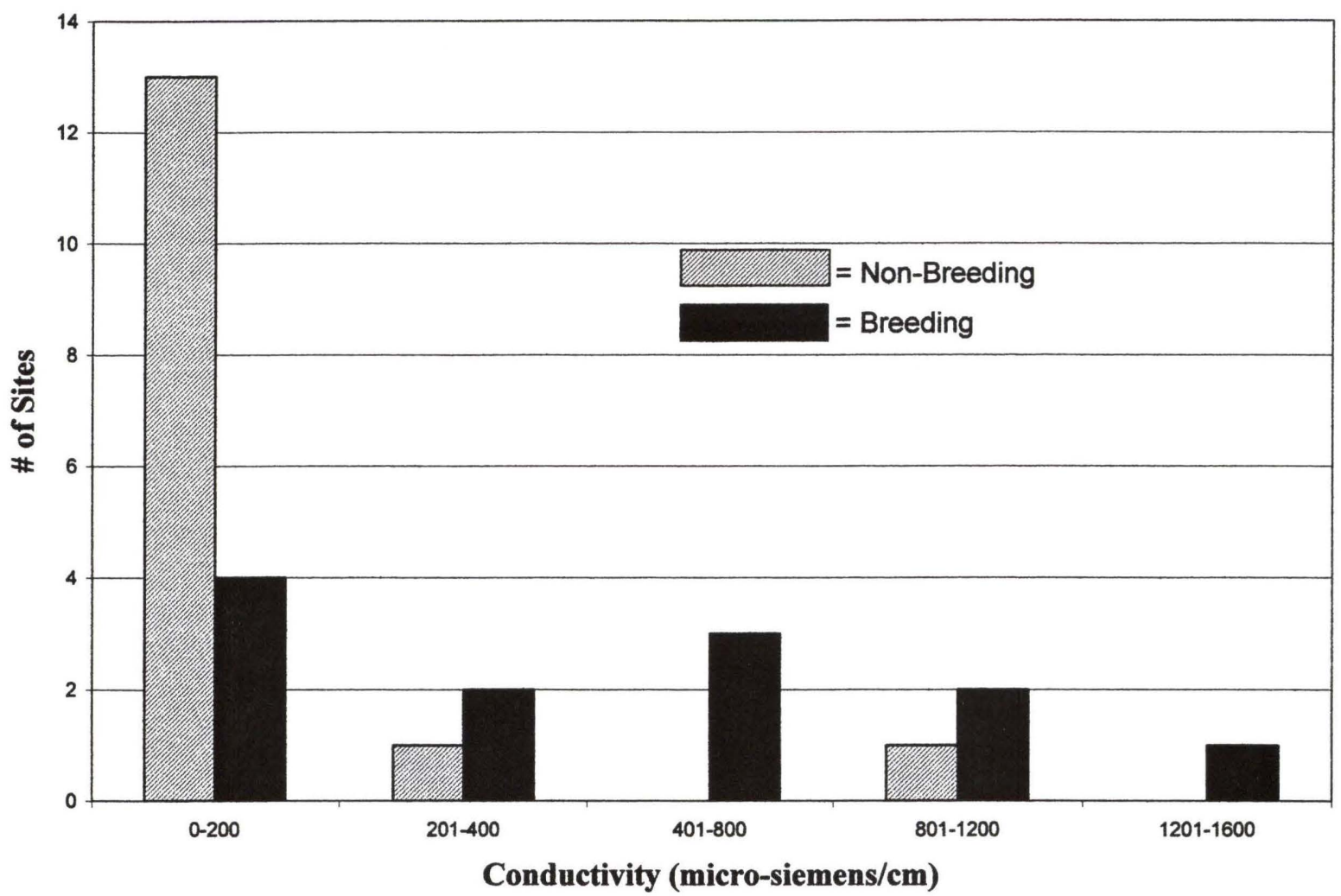

Figure 2. Breeding and non-breeding group membership as demonstrated by conductivity.

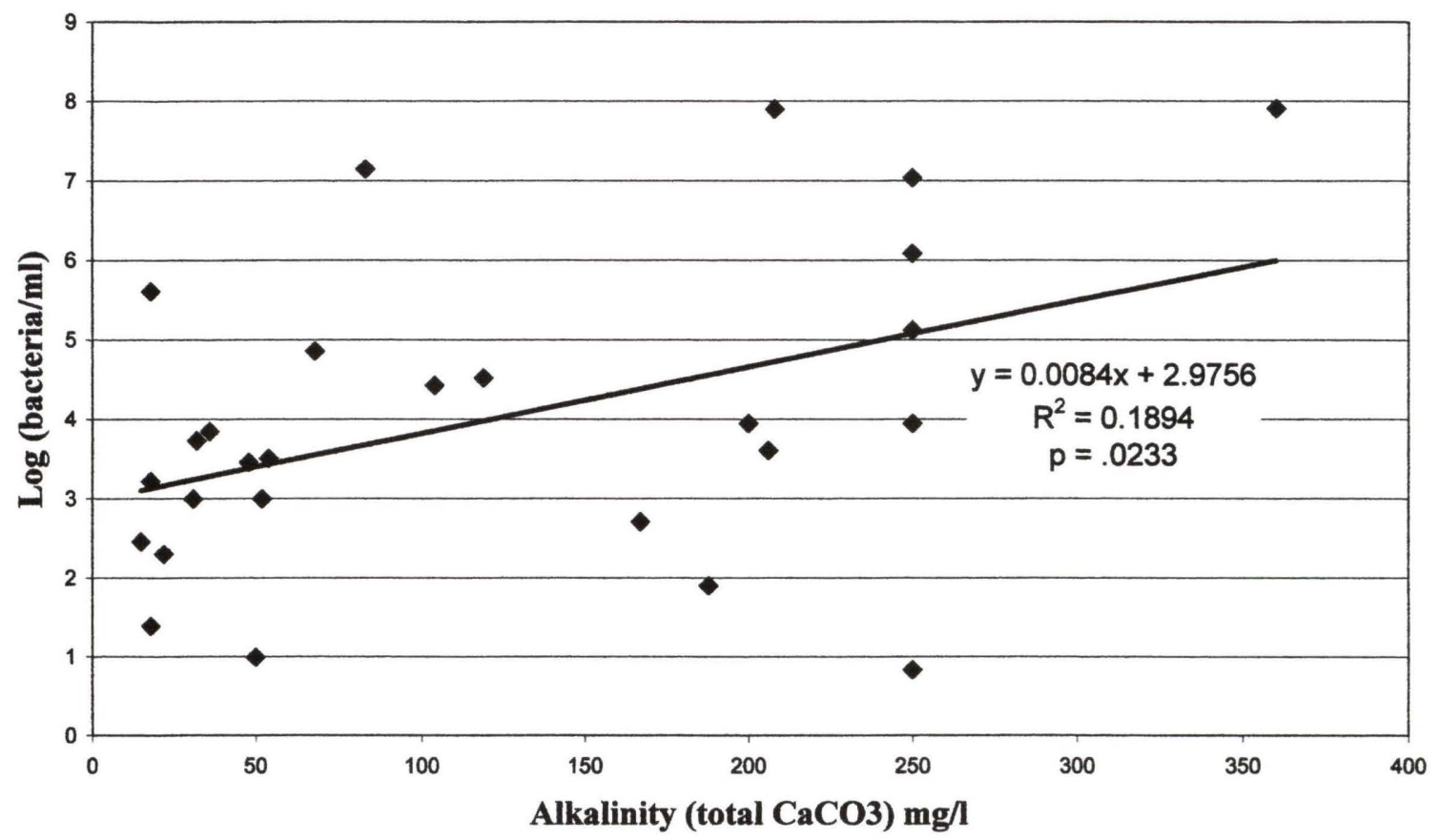

Figure 3. The regression of $\log ($ bacteria/ml $)$ verses alkalinity. 


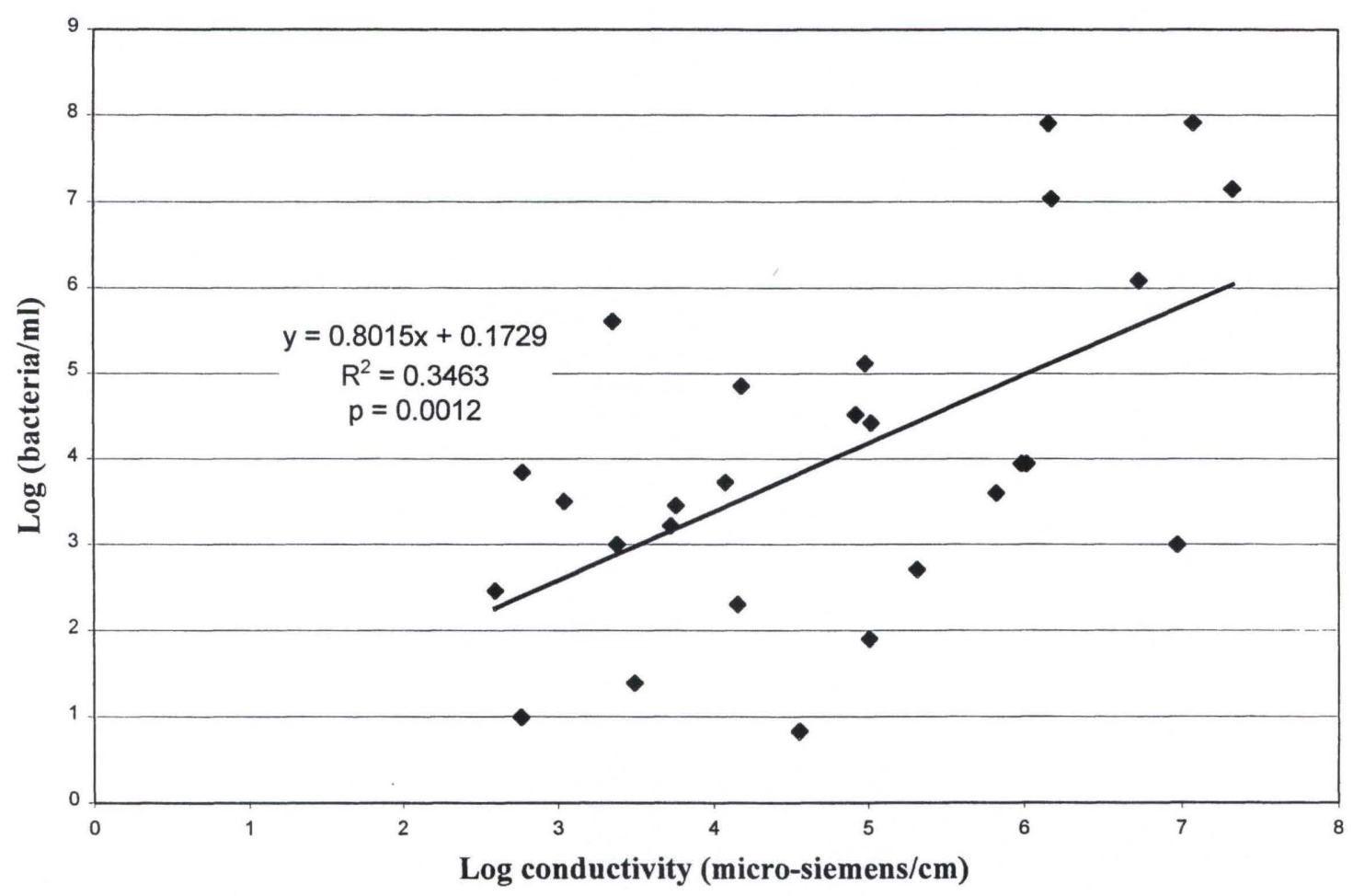

Figure 4. Regression plot for log (bacteria/ml) verses log (conductivity).

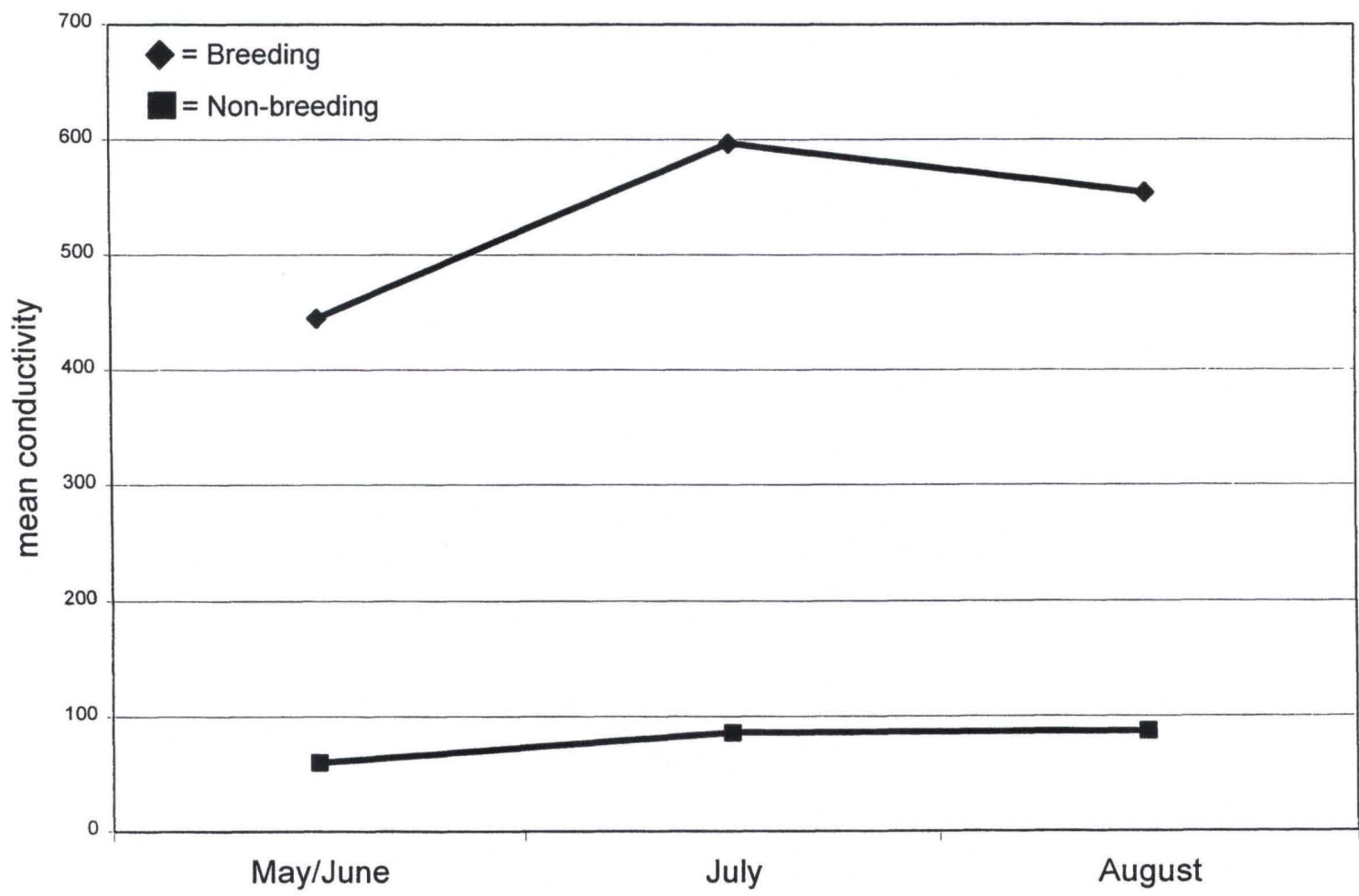

Figure 5. Changes in conductivity during 1997 within the four breeding and nonbreeding sites sampled two additional times. 